6. Іваницька Н. Л., Борейко Т. В. Статистика в мові науковотехнічного стилю. Science and education: problems, prospects and innovation. - Abstracts of International and Practical Conference. (Kyoto, Japan. 4-6 February, 2021) - C. 505-509.

7. Кочерган М. П. Основи зіставного мовознавства. Київ : Академія, 2006. $424 \mathrm{c}$.

8. Родюк Н. Семантико-теоретичний аналіз національно маркованої лексики історичного твору // Наукові записки Вінницького держсавного педагогічного університету імені Михайла Коиюбинського. Серія: Філологія (мовознавство): Зб. наук. праць / гол. ред. С. Б. Барань. Вінниця : ТОВ «Фірма Планер», 2020. Вип. 31. С. 71-77.

9. Селіванова О. О. Сучасна лінгвістика : напрями та проблеми : підручник. Полтава : Довкілля. Київ, 2008. 712 с.

10. Сучасний словник іншомовних слів. Близько 20 тис. слів і словосполучень / уклад. О. І. Скопненко, Т. В. Цимбалюк. Київ : Довіра, 2006. $789 \mathrm{c}$.

DOI https://doi.org/10.30525/978-9934-26-073-5-2-14

\title{
ТЕРМІН ЯК ОДИНИЦЯ МОВИ СПЕЦАЛЬНОГО ПРИЗНАЧЕННЯ В ЛІНГВІСТИЧНИХ ДОСЛІДЖЕННЯХ
}

\author{
Мельник П. В. \\ магістр філології, народний депутат України, \\ голова підкомітету з питань координації програм \\ технічної допомоги Свропейського Союзу та співпраиі з Свратомом \\ Комітету Верховної Ради Украӥни з питань інтеграції Украӥни \\ з Свропейським Союзом \\ м. Київ, Украӥна
}

Професійна підмова як феномен (субмова, підмова, соціальнопрофесійний варіант мови, мова спеціального призначення, LSP language for specific purposes) потрапляе в активний науковий обіг у другій половині XX ст. На першому етапі (60-80 рр. XX ст.) професійну підмову розглядають 3 позицій загального термінознавства та функціональної стилістики. Увага вчених зосереджена на формальних характеристиках мова спеціального призначення, iï лексичному складі й граматичних особливостях. Основними джерелами дослідження були наукові й технічні тексти. У 90 -ті роки XX ст. сформувалася особлива 
галузь гуманітарного знання - лінгвістика LSP (лінгвістика мов спеціального призначення), яка на перший план висунула проблему лінгвістичного статусу підмов, їхню функціонально-семіотичну неоднорідність і місце в системі національної мови; саме в цей час у науковий обіг потрапляють окремі професійні підмови, які розглядаються не тільки 3 формальної, але й з функціональної позиції. На початку XXI століття важливості набуває завдання дослідження мов спеціального призначення з позиції когнітивно-дискурсивної парадигми, а також контрастивної соціолектології [4; 7].

Сучасному етапу розвитку лінгвістичної науки притаманна пильна увага науковців до проблем інституціональної комунікацій, до професійної мовної картині світу, а також до мов спеціального призначення, які забезпечують професійну комунікацію. Особливою рисою новітнього розвитку лінгвістики мов спеціального призначення й термінознавства $\epsilon$ широке впровадження міждисциплінарних i трансдисциплінарних методик.

Мова спеціального призначення в лінгвістиці аналізується 3 позицій різних парадигм: когнітивно-дискурсивної та комунікативної.

Феномен професійних підмов став предметом дослідження в теоретичній лінгвістиці на початку 60-х рр. XX ст. Одним із перших, як відомо, визначення поняття «підмови» запропонував М. Андреєв: «набір мовних елементів і їхніх відносин у текстах з однорідною тематикою» [1, с. 91]. Але таке визначення стало предметом дискусії для частини мовознавців, які пропонували оригінальні концепції сутності підмови, справедливо вимагаючи акцентувати увагу не лише на їі словниковому складі, але й на функціях та місці в складі національної мови. Зауважимо, що терміни «підмова» й «мова спеціального призначення» у сучасних лінгвістичних роботах вживають як синоніми.

На дамку А. Комарової, «мова спеціального призначення (LSP) - це професійно орієнтований регістр мови, що функціонує в тих галузях знань, які мають власну глибоку й розгалужену систему понять; у мовному розрізі LSP характеризується певною ідіоматичною й стилістичною обмеженістю» [6, с. 34]. В. Коровушкін наголошує на історичній сформованості, відносній сталості у певному періоді автономної екзистенціальної форми національної мови зі своєю системою взаємопов'язаних соціолінгвальних норм різних рівнів і набором фонетичних, граматичних i, переважно, специфічних лексичних засобів загальнонаціональної мови для забезпечення мовного спілкування окремого соціуму з характерним поєднанням професійно-корпоративної діяльності індивідів і відповідної системи спеціальних понять [7, с. 12]. 
На нашу думку, професійна підмова - це один із численних варіантів втілення загальнонаціональної мови, специфічна функціонально-семіотична підсистема для професійної комунікації з метою акумуляції, трактування та передачі спеціальних знань і досвіду, відображення професійної мовної картини світу й оцінювання предметів професійної діяльності.

Теоретичний напрям дослідження професійної підмови вирішує проблеми онтологічних властивостей підмови, iï структури та функцій, неоднорідності підмов стосовно предметних галузей i загальнонаціональної мови загалом.

Основу історико-лінгвістичного підходу становить сприйняття професійних підмов як складних динамічних підсистем мови. Достатньо розлого історичну концепцію професійних мов представляє у своїх дослідженнях О. Фельде. Авторка зазначає, що динамічні процеси в складі спеціальної лексики $є$ головною умовою функціонування певної підмови. Лише пристосовування до постійно змінюваних зовнішніх i внутрішніх умов існування, може забезпечити їй ефективне виконання основних функції й забезпечити професійну комунікацію [12, с. 52]. Цілком зрозуміло, що для комплексної характеристики процесу розвитку певної професійної підмови потрібно аналізувати взаємовпливи актуальних у конкретний історичний період і екстаралінгвальних чинників розвитку мови, і іiі внутрішніх законів. Науковці, які здійснюють дослідження мови спеціального призначення 3 позицій дискурсу й когнітивістики, відзначають, що виявлення засадничих характеристик мови спеціального призначення уможливилось і розширилось із розвитком когнітивної науки й когнітивної лінгвістики, а також наголосили на необхідності звернення при визначенні різних явищ мови до ії міждисциплінарих контактів. В. Новодранова вважає, що дослідження LSP, на підставі тільки на лінгвістичної інтерпретації цього поняття не можливе, адже це явище поєднує спеціальні знання в певній галузі й способи їхньої репрезентації в мові [9, с. 139]. Процес вивчення професійних підмов базується на аналізі взаємовпливів структур спеціального знання й структур мови. Нову концепцію LSP, розроблену на підставі когнітивно-дискурсивного підходу, представила А. Зяблова: мова спеціального призначення - «... система, що розвиває лінгвістичні засоби загальнонаціональної мови, яка (особливо в сфері лексики) репрезентує структури знання, що склалися в певний період розвитку науки й демонструють досягнутий у цей період особливий рівень розвитку в конкретній предметній галузі знань, який важливий для соціуму й забезпечує його власний розвиток і прогрес» [4, с. 35]. 
В основі мов спеціального призначення, безумовно, перебувають одиниці спеціальної номінації - терміни. Власне термін 3 позицій когнітивно-дискурсивного підходу до вивчення професійних підмов містить особливі структури знань, властиві мовам спеціального призначення. Характеризуючи LSP важливо аналізувати не лише склад термінологічної лексики, а й виокремлювати релевантні для неї основні поняття: якщо певний слот фрейму посідає вище місце, то більшою є і ймовірність потрапляння його назви до переліку ключових понять. Ключові поняття можна визначати, на думку О. Зяблової, за наступними критеріями: значущість поняття в науці; залучення його до значного пласту лексики в якості і першого, і останнього елемента композитів чи багатослівних утворень; залучення його до складу дефініцій інших термінів [4, с. 8$]$.

У докогнітивному періоді мовознавства термін інтерпретували як слово чи словосполучення в спеціальній галузі знань з інформативністю як основною функціональною ознакою [3, с. 246]. Але, як зазначає Т. Стасюк, такий підхід видавався неповним, адже «...поняття терміна в межах когнітивного термінознавства значно об'ємніше. Він не тільки містить певну інформацію про певне значення, явище, процес, а й спирається на сукупність знань, досвіду, накопиченого людством. Формування когнітивного підходу в термінознавстві дозволило розвинути новий погляд на термін як репрезентант наукового знання, засіб здобування, зберігання та накопичення професійно-наукової інформації. У межах цього підходу основну одиницю науки розглядають як вербалізований результат фахового мислення, оскільки в мові об'єктивуються результати пізнавальної діяльності людей» [11, с. 75 ].

Заслуговує на увагу й така особливість когнітивно-дискурсивного підходу до вивчення мов спеціального призначення, як функціонування термінів у типологічно різних текстах. Вона вказує на необхідність виділення критеріїв визначення типу текстів: аналіз показників насиченості текстів термінами; дослідження процесів термінологізації і детермінологізації тощо. Дискурсивні дослідження розглядають LSP як лінгвістичний ресурс професійного дискурсу. Поза межами комунікативних засобів професійний дискурс формує вербально опосередкована професійна діяльність [5, с. 77].

Більшість лінгвістичних робіт, у яких досліджується мова спеціального призначення в цілому чи з огляду на ії лексичний склад, багатоаспектні, поліпарадигмальні й поєднують різні наукові підходи. Як зазначає Л. Архипенко, «...марковані одиниці професійних підмов мають високу лінгвістичну інформативність і тому повинні залучатися до аналізу інституціональних дискурсів, професійної мовної картини 
світу» [1, с. 21]. Значний обсяг наукових робіт з вивчення LSP засвідчує широке й глибоке дослідження окресленого феномена, але низка питань залишається дискусійною, адже остаточного визначення не мають статус, межі та структура мови спеціального призначення. Це спричинено, на нашу думку, паралельним використанням терміна «підмова» декількома науками, і кожна в дефініцію цього поняття вкладає різні значення.

Отже, дослідження професійних підмов (мов спеціального призначення) подолало шлях від вивчення формальної структури лексем через аналізування тексту (професійного дискурсу) до вивчення ментальності, ціннісного простору професіонала, професійної мовної картини світу.

\section{Література:}

1. Андреев Н. Д. Распределительный словарь и семантические поля / Статистико-комбинаторное моделирование подъязыков: сб. науч. cm. / Под ред. Н. Д. Андреева. М.; Л.: Наука, 1965. С. 490-497.

2. Архипенко Л. М. Засоби професійної комунікації та спеціальні найменування в наукових традиціях / Науковий вісник Міжнародного гуманітарного університету. Сер.: Філологія. 2020. № 46, том 1. С. $18-22$.

3. Даниленко В. П. Русская терминология: Опыт лингвистического описания. Москва: Наука, 1977. 246 с.

4. Зяблова О. А. Принципы исследования языка для специальных целей: на примере языка экономики: дис. ... д-ра філол. н.: 10.02.19. Москва, 2005. 314 с.

5. Казакова Д. В. Категория комического в медицинском дискурсе: дис. ... канд. филол. н.: 10.02.19. Красноярск, 2013. 312 с.

6. Комарова А. И. Функциональная стилистика: научная речь. Язык для специальных целей (LSP). Изд. 3-е. М.: Издательство ЛКИ, 2010. $192 \mathrm{c}$.

7. Коровушкин В. П. Основы контрастивной социолектологии: автореф. дис. ... Д-ра филол. н.: 10.02.20. Пятигорск, 2005. 48 с.

8. Лейчик В. М. Профессиональная и непрофессиональная лексика в профессиональных и непрофессиональных LSP / Вестник Челябинского государственного университета. Филология. Искусствоведение. Челябинск, 2011. № 24 (239). Вып. 57. С. 29-32.

9. Новодранова В. Ф. Фон и фигура в языке для специальных целей Концептуальное пространство языка: сб. науч. тр. Посвящается юбилею профессора Николая Николаевича Болдырева / Под ред. проф. Е. С. Кубряковой; Федеральное агентство по образованию, 
Тамб. гос. ун-т. им. Г. Р. Державина. Тамбов: Изд-во ТГУ им. Г. Р. Державина, 2005. С. 455-457.

10. Півньова Л. В. Мова спеціального призначення як об'єкт лінгвістичних студій / Українська мова. 2014. № 4 (52). С. 117-126.

11. Стасюк Т. В. Терміносфера новітніх технологій: лінгвосоціокогнітивні чинники формування та розвитку: дис. ... д-ра філол. н.: 10.02.01. Київ, 2020. 518 с.

12. Фельде О. В. Языки для специальных целей в историколингвистическом аспекте / Вестник Бурятского государственного университета. Улан-Удэ, 2013. № 10. С. 50-55.

DOI https://doi.org/10.30525/978-9934-26-073-5-2-15

\title{
COMMUNICATIVE AND PRAGMATIC FEATURES OF DRAMATIC TEXTS
}

\author{
Moskalchuk H. O. \\ PhD student of the Institute of Philology \\ Borys Grinchenko Kyiv University \\ Kyiv, Ukraine
}

At the initial stage of its development, pragmatics and its constituent the speech act theory developed by J. Austin and R. Searle - dealt with studying the principles of live communication. In due course, the opinion was formed that the pragmatic aspect is extremely important in the study of a literary text [5].

This article aims to analyze lingual pragmatic features of dramatic text manifested through wordplay.

Indirectness of the pragmatic aspect of the literary text is stipulated by the following: firstly, the author expresses their attitude to reality not directly, but through the prism of the characters; secondly, the author/reader is considered to be generalized predicted communicant (the addressee is not an individual, but a wide range of readers); thirdly, the success of the communication depends on many extratextual factors, such as reader's thesaurus, etc. These features require the author to carefully select linguistic expressive means that will enable the reader to adequately decode the text. In such a case, readers are inherently assumed to be conservatives, while writers should be the embodiments of innovative potential. The perception of the literary text is subject to a framework, which main task is to ensure the maximum possible 